\title{
SATB1 wt Allele
}

National Cancer Institute

\section{Source}

National Cancer Institute. SATB1 wt Allele. NCI Thesaurus. Code C74435.

Human SATB1 wild-type allele is located in the vicinity of 3p23 and is approximately $77 \mathrm{~kb}$ in length. This allele, which encodes DNA-binding protein SATB1, is involved in DNA binding and may play a role in transcriptional regulation. The expression level of the gene is associated with the metastatic potential of breast cancer cells. 